\title{
The Gospel of Matthew within the context of Second Temple Judaism
}

\author{
C. R. Holladay \\ Emory University's Candler School of Theology, \\ Rita Anne Rollins Building, 1531, Dickey Drive, Atlanta, Georgia, 30322, USA
}

For citation: Holladay C.R. The Gospel of Matthew within the context of Second Temple Judaism. Issues of Theology, 2020, vol. 2, no. 2, pp. 341-367.

https://doi.org/10.21638/spbu28.2020.210

The author's aim is to analyse the Gospel of Matthew within the broader literary tradition of Second Temple Judaism. The Jewish writings produced both in the land of Israel and in the diaspora from the Hasmonean period until the early Empire help us to relate Matthew to its social, political and theological context. Surveying some aspects of the Second Temple Judaism, namely Messianic expectations, Apocalyptic movements and Scripture interpretation methods, bear valuable evidence on how Matthew sets the story of Jesus. Treatises of such prolific authors as Philo and Josephus provide valuable literary parallels as well as an overall outlook on major trends of thought, that need to be taken into account when interpreting the Gospel of Matthew. Matthew's portrait of Jesus as a royal figure, as the legitimate heir of the House of David is, to some extent, linked with the understanding of kingship during the Hasmonean period. The kingship motif is prominent for Philo's De vita Mosis, in which Moses is treated as king, legislator, priest, and prophet. Comparative analysis leads the author to the question of whether it is possible to include Matthew, and even the other three canonical Gospels, within one of the standard collections of Jewish writings?

Keywords: Biblical studies, New Testament, Gospel of Matthew, Second Temple Judaism, messianism, apocalyptic movements.

\section{Introduction}

I have been asked to speak about the Gospel of Matthew within the broader context of Second Temple Judaism. When read alongside the Jewish writings that were produced both in the land of Israel and in the diaspora between $200 \mathrm{BCE}$ and 200 CE, how does Matthew look? With which Jewish writings does it bear close affinity either in terms of literary genre or overall outlook? If we were asked to include Matthew, and even the other three canonical Gospels for that matter, within one of the standard collections of Jewish writings from this period, where would we place it? ${ }^{1}$ Would it easily fit into one of the usual literary categories

${ }^{1}$ Among the most notable are: Charles R. H. The Apocrypha and Pseudepigrapha of the Old Testament in English: in 2 vols. Oxford: Oxford University Press, 1913; repr. 1965; Charlesworth J. H. The Old Testament Pseudepigrapha: in 2 vols. New York: Doubleday, 1983-1985; Kümmel W. G.,

(c) Санкт-Петербургский государственный университет, 2020

(C) Общецерковная аспирантура и докторантура им. святых равноапостольных Кирилла и Мефодия, 2020 
such as apocalypse, testament, or wisdom literature? Or would we have to create a new section in the Table of Contents to include Matthew?

Matthew has generated a prodigious amount of scholarly research and publications over the past several decades. Although numerous, often conflicting, lines of interpretation have been pursued, there is broad agreement on some basic issues ${ }^{2}$. Most agree that Matthew reflects awareness of the destruction of the Jerusalem temple in $70 \mathrm{CE}$, and that it was probably composed in the last quarter of the first century $\mathrm{CE}^{3}$. Where Matthew was written is still disputed. Some argue for a Palestinian provenance such as Jerusalem, Caesarea Maritima, or somewhere in Galilee, while others think Syrian Antioch the most probable context of origin ${ }^{4}$. Everyone would agree that its narrative focus is "the land of Israel" $(2: 20,21)$, although its geographical horizon sometimes extends beyond Palestine to "the East" (2:1) and to Egypt (2:13-23). Matthew nowhere mentions Rome or any other major Mediterranean city such as Alexandria or Antioch on the Orontes.

Two regions of the Palestinian mainland are the main focus of attention: Galilee $^{5}$ and Judea ${ }^{6}$, with no mention of Samaria as a geographical region ${ }^{7}$. Matthew's geographical horizon is aptly captured in the narrative summary of 4:25: "And great crowds followed him from Galilee, the Decapolis, Jerusalem, Judea, and from beyond the Jordan". Within Galilee the main geographical locations around which the narrative is constructed are Nazareth", "the Sea of Galilee" and Capernaum ${ }^{10}$, with occasional references to paired cities such as Chorazin and Bethsaida ${ }^{11}$, Tyre and Sidon ${ }^{12}$, and more remote places such as Caesarea Philippi ${ }^{13}$. The main location in Judea is Jerusalem ${ }^{14}$, although initially the

Habicht C. et al. (Hrsg.) Jüdische Schriften aus hellenistisch-römischer Zeit: in 6 dn. Gütersloh: Gütersloher Verlagshaus, 1973-1999; Feldman L.H., Kugel J.L., Schiffman L.H. (eds). Outside the Bible: Ancient Jewish Writings Related to Scripture: in 3 vols. Philadelphia, 2013.

${ }^{2}$ Summaries of recent scholarship on Matthew are readily available in: Davies W. D., Allison D. C. A Critical and Exegetical Commentary on the Gospel According to Saint Matthew: in 3 vols (International Critical Commentary). Edinburgh: T\&T Clark, 1988-1997 (further on Davies W.D., Allison D. C. Matthew); Luz U. Matthew : in 3 vols / transl. by J. E. Crouch. Minneapolis: Fortress Press, 2001-2007.

${ }^{3}$ Matt 22:7; 24:15. See the discussion of dating in: Davies W.D., Allison D. C. Matthew. Vol. 1. P. 127-138, who date it between 80 and 95 CE; Luz U. Matthew. Vol. 1. P. 58-59, dates it around 80 .

${ }^{4}$ Davies W.D., Allison D. C. Matthew. Vol.1. P. 138-47, favor Antioch of Syria; similarly: Luz U. Matthew. Vol. 1. P.56-58.

${ }^{5}$ Matt 2:22; 3:13; 4:12, 15, 18, 23, 25; 15:29; 17:22; 19:1; 21:11; 26:32; 27:55; 28:7, 10, 16.

${ }^{6}$ Matt 2:1, 5, 22; 3:1, 5; 4:25; 19:1; 24:16.

7 Matthew refers once to "the Samaritans" (10:5).

${ }^{8}$ Matt 2:23; 4:13; 21:11; 26:71.

${ }^{9}$ Matt 4:18; 15:29.

${ }^{10}$ Matt 4:13; 8:5; 11:23; 17:24.

11 Matt 11:21.

12 Matt 11:21-22; 15:21.

${ }_{13}$ Matt 16:13.

${ }^{14}$ Matt 2:1, 3; 3:5; 4:25; 5:35; 15:1; 16:21; 20:17-18, 21:1, 10; 23:37. 
Judean focus is on Bethlehem ${ }^{15}$. Judea is also linked with the vaguely described region "beyond the Jordan" ${ }^{16}$. Naturally this assumes that the Jordan River, with which the ministry of John the Baptist was associated, is a major geographical marker on Matthew's map of "the land of Israel"17.

Although Papias's early testimony that Matthew was based on an Aramaic (or Hebrew) original has generated numerous theories about the original language of composition, no such text has survived ${ }^{18}$. The textual tradition of Matthew is traceable only to a Greek original, which began to be translated into other versions at an early date. Although written in Greek, Matthew is clearly Jewish in ethos, outlook, and texture. Its Jewishness is one of the earliest features of the patristic tradition relating to Matthew: It was written by a Jew for a Jewish audience. Accordingly, we can think of Matthew as a Hellenistic Jewish writing - a text written in Koine Greek by a Jew. As for the overall literary quality of Matthew's Greek, any assessment must take into account the presence of numerous Semitisms throughout the narrative, and the degree to which these are derived from earlier sources or are the author's own creation. But as C.F.D. Moule observes, "there are passages [in Matthew] where we find quite accomplished Greek, free from Semitisms", and "one might say that the editor was an educated person commanding sound Greek with a considerable vocabulary; but he derived many Semitisms, and perhaps some Latin, from his sources; and he also had some feeling for Semitic 'atmosphere', occasionally introducing a Semitism on his own account, though less histrionically than Luke"19. Whether Matthew's main biblical text was Hebrew or Greek, or a combination of the two, is an equally complicated question, but his biblical quotations often display Septuagintal features ${ }^{20}$.

\section{Some Distinguishing Features of Second Temple Judaism}

How to characterize a religious tradition or movement as complex and controversial as Judaism during the Second Temple period is a perennial challenge. Recent scholarship is rightly critical of earlier interpretive categories such as

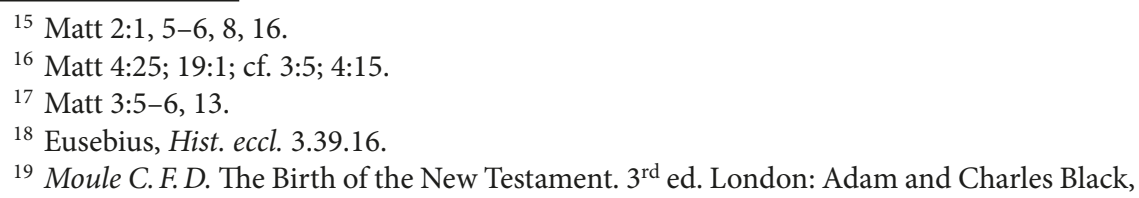
1981. P. 278, 280.

${ }^{20}$ See: Davies W.D., Allison D. C. Matthew. Vol.1. P.32-33. - Acknowledging that some (Bacon, Clark, and Strecker) have argued for Matthew's exclusive use of the LXX, but arguing instead that Matthew knew the OT in both Hebrew and Greek. Determining Matthew's source text for a particular OT quotation or allusion is complicated by the fact that a particular quotation or allusion may have derived from one of the other synoptic Gospels rather than from his independent use of the OT. The charts (p. 34-57) display the variety of ways in which Matthew's quotations tend to follow the LXX or the MT. One must, for example, distinguish between the 10-12 formula quotations in Matthew and the non-formula quotations, the latter of which "are generally LXX in form or exhibit only minor variations from the LXX" (52). See: Stendahl K. The School of St. Matthew and Its Use of the Old Testament. $2^{\text {nd }}$ ed. (Acta Seminarii Neotestamentici Upsaliensis 20). Lund, Gleerup, 1967, esp. his analysis of the formula quotations (97-127). 
Spätjudentum, "normative Judaism", "post-biblical" or even "intertestamental" Judaism, and also of characterizations that highlight the purported hyper-legalism or moribundity of Judaism during the pre-Christian period ${ }^{21}$. Simplistic, monochrome descriptions have given way to more nuanced efforts to capture the diversity and complexity of Jewish beliefs, practices, and traditions in the Hellenistic and early Roman periods. While some now prefer to speak of "Judaisms" - identifiably discrete systems of Jewish belief and practice - rather than "Jewish diversity" or "varieties of Judaism", others still insist that it is possible to speak of a "common Judaism" - a set of core beliefs, texts, and traditions based on Torah but also informed by prophetic and wisdom texts ${ }^{22}$.

S. J.D. Cohen has argued convincingly that Judaism between 200 BCE and $200 \mathrm{CE}$, far from being anemic and legalistic, displays remarkable levels of literary activity that are creative and innovative in responding to the new social-political realities, first, of Hellenism as exemplified in the Ptolemies, Seleucids, and Antigonids, and, later, of Rome during the late Republic and the early Empire ${ }^{23}$. Drawing on earlier prophetic and even wisdom traditions, Jewish apocalyptic movements emerged in different settings, displaying admirable resilience in responding to oppressive political realities by constructing a viable counter-culture, at least in the imagination if not in actual communities and social structures. Among other things, this sustained stream of intellectual vitality and literary productivity reflected a commendable form of democratization in which the interpretation of Scripture and tradition moved outside official circles that were directly connected to well established institutions such as the temple, and were embraced by those empowered by their own intellect and independent spirit. Over time, these democratic impulses saw the origin and development of identifiable groups such as Pharisees, Sadducees, Essenes, to name Josephus's top three, with the possible addition of the Zealots later on ${ }^{24}$. Inevitably, these discrete groups and their traditions competed with each other, even as they were embraced by different sectors of Jewish society.

The sheer volume of writings produced during this period, whether categorized as "apocryphal" or "pseudepigraphical", that is, as they are understood in relation to the Jewish Scriptures, or as they occur in such prolific authors as Philo of Alexandria in the early first century CE and Josephus later in that same century, attests to this intellectual ferment. A central ingredient of this same intellectual movement is the emergence of the Greek Scriptures, gradual to be sure,

${ }^{21}$ See: Nickelsburg G. W.E., Kraft R. A. Introduction: The Modern Study of Early Judaism // Early Judaism and Its Modern Interpreters / eds R. A. Kraft and G. W.E. Nickelsburg. Atlanta: Scholars Press, 1986. P. 1-30, esp. 1-2.

${ }^{22}$ See: Judaisms and Their Messiahs at the Turn of the Christian Era / eds J.Neusner, W. S. Green, E. S. Frerichs. Cambridge: Cambridge University Press, 1987; Sanders E. P. Judaism: Practice and Belief, 63 BCE - 66 CE. London: Trinity Pr Intl, 1994, esp. Part II "Common Judaism" (p. 45-314).

${ }^{23}$ See: Cohen S. J.D. From the Maccabees to the Mishnah. $3^{\text {rd }}$ ed. Louisville: Westminster John Knox Press, 2014.

${ }^{24}$ Josephus B. J. 2.119-166; A. J. 18.11-25. 
but eventually complete. While the origins of this major literary accomplishment remain obscure, the general outlines are fairly clear, aided and abetted, of course, by the production of the Letter of Aristeas, itself an effective piece of literary propaganda that appeared sometime between the end of the third century BCE and the first century CE.

The emergence of Matthew, along with the other Gospels, as well as the other writings of the NT, should be seen within this broader context of literary productivity that characterized Second Temple Judaism. When the earliest followers of Jesus began collecting and preserving oral and written traditions about their central cultic figure, and eventually began writing their own accounts of his life and teaching, they were responding to religious, intellectual, and literary impulses that had already been in place within Judaism for two centuries or more. Their willingness to appropriate old, well-established literary genres such as the letter and biography reflected patterns of literary innovation that had already begun in Alexandria in the second century BCE and that had developed in other places as well ${ }^{25}$.

Yet another feature of Second Temple Judaism that bears directly on Matthew is messianic expectation ${ }^{26}$. How one construes various Jewish texts from this period, especially those that appropriate such OT texts as Num 24, Isa 11, or the "servant songs" of Isa 42-53, constitutes a major challenge for interpreters of Matthew. Efforts to reconstruct Jewish messianic thinking by assembling motifs from relatively late texts such as 4 Ezra (late first century) and 2 Baruch (early second century), and then producing clear messianic profiles that are thought to have been present a century or two earlier, have now given way to more nuanced analysis in which the various texts that speak of messianic figures or hopes are interpreted in their respective historical contexts.

As J.J.Collins observes, "Messianic references in the Pseudepigrapha are sparse. There is no evidence of messianism at the time of the Maccabean revolt, and indeed messianic expectations seem to have been dormant throughout

25 The case for seeing Graeco-Roman $\beta$ ío as a well-defined literary genre that was appropriated by Jewish authors such as Philo of Alexandria and by the early Christian writers who composed the canonical Gospels has been argued convincingly by: Burridge R. What Are the Gospels? A Comparison with Graeco-Roman Biography. $2^{\text {nd }}$ ed. Grand Rapids, Cambridge, WM. B. Eerdmans Publishing Co, 2004; a forthcoming third edition is scheduled for publication by Baylor University Press; also see: Niehoff M.R. Philo and Plutarch as Biographers: Parallel Responses to Roman Stoicism // Greek, Roman, and Byzantine Studies. 2012. Vol. 52. P.361-392.

${ }^{26}$ From the vast bibliography on Jewish notions of messiahship during the Second Temple period, I am indebted to J.J. Collins's numerous publications in which he explores this theme. Especially informative is his "Jesus and the Messiahs of Israel", in idem: Collins J.J. Encounters with Biblical Theology. Minneapolis: Fortress Press, 2005; also, idem: Collins J. J. The Scepter and the Star: Messianism in Light of the Dead Sea Scrolls. $2^{\text {nd }}$ ed. Grand Rapids: Wm. B. EerdmansLightning Source, 2010; Collins A. Y., Collins J.J. King and Messiah as Son of God: Divine, Human, and Angelic Messianic Figures in Biblical and Related Literature. Grand Rapids: Wm. B.Eerdmans Publishing Co, 2008; Oegema G. S. The Anointed and His People: Messianic Expectations from the Maccabees to Bar Kochba (Journal for the study of the pseudepigrapha: Supplement series 27). Sheffield: Bloomsbury T\&T Clark, 1998. 
much of the Second Temple period. When we find a resurgence of messianism in the Dead Sea Scrolls, we find not just one messiah, but, in the classic phrase of 1QS 9:11, the expectation of 'a prophet, and the messiahs of Aaron and Israel"'27. Rather than seeing unsystematic messianic conceptions scattered throughout the Dead Sea Scrolls, Collins finds a fairly well-defined understanding of a priestly messiah that reflected the priestly orientation of the Qumran sect. He also finds a generally coherent notion of a royal, Davidic messiah that was especially influenced by Isa 11 and Num 24, and whose militant role as "the Prince of the Congregation" necessarily included inflicting violence, especially against gentiles ${ }^{28}$.

On the controversial question of whether the notion of a suffering or dying Messiah is attested in Jewish thought prior to Jesus, Collins finds no evidence for such thinking in the Dead Sea Scrolls. Of particular interest to Collins is the way in which different messianic conceptions, as expressed in certain titles such as Messiah, Son of Man, and Son of God, begin to be used interchangeably or even become blended within a single figure. Reflecting late nineteenth and early twentieth-century scholarship, Schweitzer distinguishes two distinct traditions of messianic thought: one expressed with Son of Man imagery mediated through Dan 7 in which a heavenly figure exercises universal dominion, which culminates in eschatological judgment at the end of history, the other using royal, Davidic imagery to envision a figure anointed by God to re-establish the house of David and inaugurate a new political order on earth ${ }^{29}$. Critical to our understanding of messianic thinking during the period prior to Jesus and contemporary with the origin and development of early Christianity is how certain terms are used and understood within such texts as 1 Enoch, which reflects a Judean provenance and was a valued text within the Qumran community prior to the Christian period ${ }^{30}$. Notable is the usage in The Book of the Similitudes (1 En. 37-71) of the expressions "Righteous One"31, "Messiah"32, "Chosen One"33, and "Son of Man"34. While a variety of biblical texts inform these usages, especially influential as source texts are Dan 7 and certain Servant Songs in Second Isai$\mathrm{ah}^{35}$. In 1 En. 48 the Son of Man, who is regarded as an agent of the Lord of the Spirits and whose revelatory role was conceived even prior to creation, is also

27 Collins J. J. Jesus and the Messiahs of Israel. P. 169.

28 1QSb; CD 7:19; 1QM 11:6-7; similarly, Pss. Sol. 17:21-25; see: Collins J. J. Jesus and the Messiahs of Israel. P. 170-171.

${ }^{29}$ Schweitzer A. The Quest of the Historical Jesus. First Complete Edition / ed. by J. Bowden. Minneapolis: Fortress Press, 2001, esp. p. 235-259. - Schweitzer characterizes these two eschatological conceptions as "prophetic and Danielic eschatology" (p. 239).

30 See: Vanderkam J. C. Righteous One, Messiah, Chosen One, and Son of Man in 1 Enoch 37-71 // The Messiah: Developments in Earliest Judaism and Christianity. The First Princeton Symposium on Judaism and Christian Origins / ed. by J.H. Charlesworth. Minneapolis: Fortress Press, 1992. P. 169-191.

31 En. 38:2; 53:6.

321 En. $48: 10 ; 52: 4$.

331 En. 39:6; 40:5; 45:3-4; 48:6; 49:2, 4; 51:3, 5; 52:6, 9; 53:6; 55:4; 61:5, 8, 10; 62:1.

${ }^{34} 1$ En. 46:2-4; 48:2; 62:5, 7, 9, 14; 63:11; 69:27, 29; 70:1; 71:14, 17.

35 Vanderkam J. C. Righteous One. P. 188-190. 
designated as "the Chosen One" (v. 6) and as "his (i. e., the Lord's) Messiah" (v. 10). But, as Collins notes, "the assimilation of the Son of Man to the Davidic messiah in the Similitudes is quite limited. The Son of Man does not appear on earth, and he is not portrayed as the fulfillment of other messianic prophecies"36.

Whether another variation of messianic function can be designated "prophetic", that is, in sharp contrast to the royal, Davidic function, and that of the eschatological Son of Man, depends on how such texts as Isa 61 were understood in Jewish thought of this period ${ }^{37}$. Luke's featuring of this text in the Nazareth Inaugural (Luke 4:16-30) clearly signals his understanding of a "prophetic anointing", but this may have more to do with Luke's distinctive conception of Jesus's prophetic role than with anything else. Here again, a Qumran text, 4Q521, the so-called Messianic Apocalypse, which draws heavily on Ps 146, may be pertinent, especially if Collins is correct in his interpretation of this text as providing

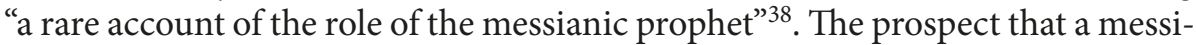
anic figure would raise the dead, a role normally reserved for YHWH, figures in Jesus's response to John the Baptist's question (Matt 11:2-5; Luke 7:22), thereby suggesting parallels between Elijah, who raised the dead, and Jesus.

Along with these messianic ideas embedded within various literary sources from the Second Temple Period, some of which are difficult to link with actual historical figures, are the reports of would-be kings, prophets, and messiahs who were part of the Palestinian landscape from the time of Pompey's arrival in 63 BCE until the Second Jewish Revolt under the leadership of Bar Kokhba in 132-135 CE ${ }^{39}$. That Simon Bar Kosiba, who sought to free Jews from Roman rule, operated with clear messianic pretensions based on Num 24:17, is widely acknowledged ${ }^{40}$. How far back into the first century such claims can be traced remains disputed, although Jewish resistance to Roman rule surfaces near the turn of the era, when Judas, son of Sepphoraeus, and Matthias, son of Margalus, two

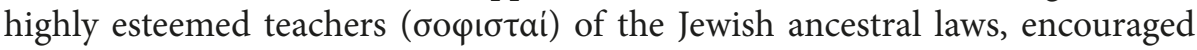
their students to remove the golden eagle that Herod had erected over the temple gate. Although Herod was near the end of his life, he executed both teachers along with their students who were the ring leaders ${ }^{41}$. In neither of his accounts

${ }^{36}$ Collins J. J. Jesus and the Messiahs of Israel. P. 172. - Collins sees a more thorough confluence of messianic traditions in 4 Ezra 13, in which a figure rises from the sea (cf. Dan 7), takes his place atop Mount Zion, from which he establishes justice, mainly by slaying the gentiles. This figure "functions as the Davidic messiah typically functions in Jewish literature of this era" (173). And yet, explicit Son of Man imagery is not found in this messianic scenario in 4 Ezra 13, and thus we do not find the same confluence of images here that occurs in 1 Enoch 3-71.

${ }^{37}$ Collins J. J. Jesus and the Messiahs of Israel. P. 175-177.

${ }^{38}$ Ibid. P. 176.

39 Ibid. P. 177, noting Josephus, B. J. 2.258-262; A. J. 20.169-171.

${ }^{40}$ See: Smallwood E. M. The Jews Under Roman Rule: From Pompey to Diocletian: A Study in Political Relations (Studies in Judaism in Late Antiquity 20). Leiden: Brill, 1981. P.428-466, esp. p. 439-440; Collins J. J. Scepter. P. 225-228.

${ }^{41}$ Josephus, B. J. 1.648-655; similarly, A. J. 17.149-167. Even after Archelaus succeeds his father Herod as king of Judea, he has to deal with continuing resistance by those who still resent Herod's actions (B. J. 2.5-13; A. J. 17.206-218). Josephus characterizes the Jewish resisters as 
of this episode does Josephus attribute messianic motives to the teachers or students; instead, he reports it as a case in which the Jewish protesters, both teachers and students, were motivated by "zeal for the law".

Josephus reports further that the power vacuum created by Herod's death in $4 \mathrm{BCE}$ "induced numbers of persons to aspire to sovereignty", including some of Herod's veterans in Idumea ${ }^{42}$. He mentions several individuals with royal ambitions, including Judas, son of Ezechias, who raised an army of followers in Sepphoris in Galilee ${ }^{43}$; Simon of Peraea, who "was proclaimed king by [the people] in their madness", and ravaged the royal palace at Jericho ${ }^{44}$; and Athronges, an obscure shepherd who appointed himself king and who, along with his four brothers, conducted guerilla warfare throughout Judea ${ }^{45}$. While none of these royal pretenders is said to have been messianic in any explicit sense, Josephus interprets their various exploits as dramatic, albeit failed, power plays to lay claim to the title "king" once held by Herod the Great.

Another outburst of anti-Roman sentiment occurred during the reign of Claudius (41-54), who organized Judea as a Roman province and placed it under direct Roman rule administered by procurators. According to Josephus, the newly appointed procurator Cuspius Fadus (44-46) aborted an uprising against Rome led by a "certain impostor ( $\gamma$ ónc) named Theudas" who claimed to be a

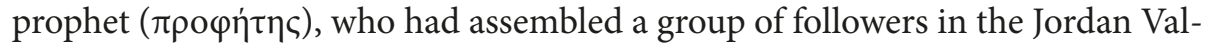
ley ${ }^{46}$. Although the details of the ideological vision that motivated Theudas are vague, Peter Schäfer is willing to identify this as the "first instance of an uprising with messianic- apocalyptic overtones" 47 . The probable basis for this claim is Josephus's phraseology suggesting that Theudas saw himself as a new Moses or Joshua: he promised that "at his command the [Jordan] river would be parted and would provide them an easy passage", thereby enabling them to proceed toward Jerusalem.

Josephus reports another episode a few years later, while M. Antonius Felix was procurator (ca. 52-60), in which an unnamed Jewish prophet, identified simply as an "Egyptian", gathered thousands of followers and led them from the desert to the Mount of Olives, with the intention of entering Jerusalem, overpowering the Roman garrison, and proclaiming himself "as tyrant of the people" (

\footnotetext{
"rebellious followers of the interpreters (of the law)" (A.J. 17.216) and their actions as sedition

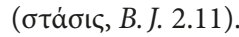

${ }^{42}$ B. J. 2.55; A. J. $17.269-270$.

${ }^{43}$ B. J. 2.56; A. J. 17.271-272.

${ }^{44}$ B. J. 2.57; A. J. 17.273-277; Tacitus, Hist. 5.9.

${ }^{45}$ B. J. 2.60-65; A. J. 17.278-284.

${ }^{46}$ A. J. 20.97-99; similarly Acts 5:36, which gives the number of Theudas's followers as 400 . On the conflict between the implied chronology of Josephus and that of Luke, see: Holladay C. $R$. Acts: A Commentary (New Testament Library). Louisville: Westminster John Knox Press, 2016.

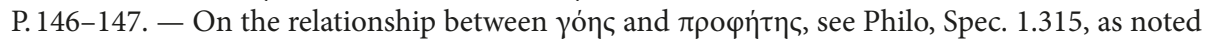
by Louis Feldman in LCL 9:440-441 n. b.

47 Schäfer P. The History of the Jews in the Greco-Roman World. London: Routledge, 2003. P. 114 .
} 


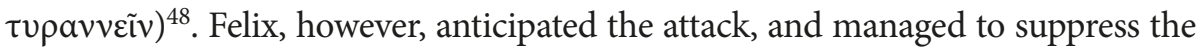
uprising by deploying the heavy Roman infantry, while also engaging popular support. Although the Egyptian prophet and some of his followers escaped, most of his forces were killed or taken prisoner. Even so, Josephus reports the continuation of similar anti-Roman uprisings fueled by calls for independence, with the result that "every day saw this war being fanned into fiercer flame" 49.

Josephus's account of a similar incident a couple of years later, during the procuratorship of Porcius Festus (60-62 CE), is less detailed than that of the Egyptian prophet ${ }^{50}$ : "[Festus's forces attacked] the dupes of a certain impostor

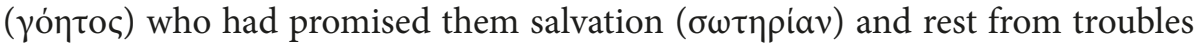
if they chose to follow him into the wilderness". In this instance, however, unlike the previous episode involving the Egyptian prophet, Festus managed to kill both the leader and his followers.

In one sense, these episodes are sporadic rather than continuous. For the most part, our main source of information is Josephus, whose pro-Roman bias is evident in both the Wars and Jewish Antiquities. Regardless of the circumstances prompting these uprisings, Josephus tends to characterize these incidents as revolutionary and seditious, as episodes in which gullible, socially disenfanchised people are duped by ambitious leaders variously described as charlatans, false prophets, and tyrants ${ }^{51}$.

While our understanding of the political situation in Palestine during the first century is incomplete in many respects, the overall picture is clear enough for us to get some sense of the historical and social setting in which Matthew can be placed. To be sure, we must distinguish between the period Matthew reports - the first three decades of the first century - and the period in which he writes - the last three decades of the first century. And we must allow for the possibility that what he reports reflects his own situation, perhaps even more so than the earlier situation he describes. But even with these methodological qualifications, we can render some plausible judgments.

On any showing, Matthew's portrait of John the Baptist has a strong prophetic element - he is introduced as the fulfillment of Isa 40:3, clothed like Elijah (2 Kgs $1: 8)$. His call for repentance and moral reform echoes the preaching of Israel's prophets. Responding to Jesus, the crowds acknowledge that "all regard John as a prophet" (21:26). Although Josephus does not call John the Baptist a prophet, he reports Herod Antipas's fear that his eloquent preaching might have revolutionary effect and "lead to some form of sedition" 52 . The Matthean portrait of Jesus has similarly explicit prophetic dimensions. The crowds respond to Jesus's "triumphal

${ }^{48}$ B. J. 2.261-263, which identifies the leader as "the Egyptian false prophet" (ó Airú $\pi \tau t o \varsigma$

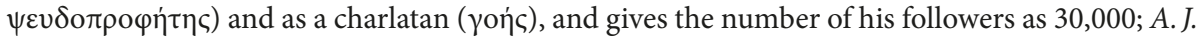
20.167-172; also, Acts 21:37-39, which reports 4000 followers.

49 B. J. 2.264-265.

${ }^{50}$ A. J. 20.188.

${ }^{51}$ See: Horsley R. A., Hanson J. S., Bandits, Prophets, and Messiahs: Popular Movements in the Time of Jesus. San Francisco: Harper Collins, 1988; orig. pub., 1985.

${ }^{52}$ A. J. 18.116-119. 
entry" into Jerusalem by saying, "This is the prophet Jesus from Nazareth in Galilee" (21:11; also, 21:46). Although the episodes involving prophets reported by Josephus occur several decades after the time of John the Baptist and Jesus, they illustrate some of the popular expectations that circulated in Palestine during the early Empire. As Acts 21:38 shows, such knowledge of local prophetic movements provided interpretive categories for understanding Paul in the early 60s.

Even more explicit than prophetic terminology is the strong Matthean portrait of Jesus as belonging to the royal, Davidic line, and the symbolic significance attached to the title "king". The central importance of this dimension of Matthew's Christology is signaled in the opening verse, "An account of the genealogy of Jesus the Messiah, the son of David, the son of Abraham" (1:1), a theme repeatedly mentioned and further developed throughout the narrative. The sheer frequency of Matthew's use of "Son of David" as a Christological title, especially in comparison with Mark and Luke, is ample proof of Matthew's construal of Jesus as a royal Messiah ${ }^{53}$. Moreover, the prominence of the ironic title "King of the Jews" in the Matthean Passion Narrative underscores the broader political context in which the narrator expected readers to situate events relating to the trial, crucifixion, and resurrection of Jesus ${ }^{54}$.

When attempting to relate Matthew to its social and political context, we cannot simply assume that the efforts of various royal pretenders whom Josephus reports as "aspiring to sovereignty" after the death of Herod the Great shaped Jewish and Roman perceptions of Jesus during his lifetime, since several decades separated those events from the time of Jesus's ministry. But if we work with a broader historical framework, extending from the Hasmonean period until the early Empire, we can see some of the ways in which various leadership, perhaps even messianic, roles functioned within the Palestinian context. This is especially true with royal and prophetic roles, along with sacerdotal roles mainly associated with the high priest.

Already during the Hasmonean period, the title "king" ( $\beta a \sigma \iota \lambda \varepsilon v$ v $)$ had acquired special significance. According to Josephus, Simon (ca. 142-135 BCE), after distinguishing himself as a military leader, was appointed high priest ${ }^{55}$, although 1 Macc 14:41-43 is more explicit in assigning him royal and priestly functions. Josephus reports that John Hyrcanus I (ca. 135-104) was unique in the way he exercised "supreme command of the nation, the high priesthood, and the gift of prophecy" 56 . According to Josephus, Aristobulus I (ca. 104-103) was the first Hasmonean leader to claim the title "king" 57 , although Strabo reports that this innovative claim was first made by Alexander Jannaeus (ca. 103-76), the successor of Aristobulus I ${ }^{58}$. Later, Aristobulus II (ca. 67-63) functioned as

${ }^{53}$ Matt 9:27; 12:23; 15:22; 20:30-31; 21:9, 15; 22:42-45.

${ }^{54}$ Matt 27:11, 29, 37; 42 (“King of Israel”); cf. 2:2.

55 B. J. $1.50-53$.

56 B. J. 1.68-69; cf. A. J. $11.299-300$.

${ }^{57}$ B. J. 1.70; A. J. 13.301.

${ }^{58}$ Strabo 16.2.40. R. Marcus, LCL 7:379 n. c, observes: “The title 'king' (melek) does not appear on the Hebrew coins of Aristobulus". 
both high priest and king ${ }^{59}$. John Hyrcanus II, the elder son of Alexander Jannaeus and Salome Alexander, was reinstated as high priest in 63, but owing to the administrative reforms of Gabinius, he was deprived of political power ${ }^{60}$. When Julius Caesar came to Syria in 47, he issued a series of decrees in which Hyrcanus

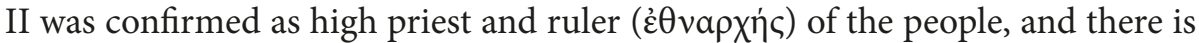
some evidence that he was seen as king ${ }^{61}$; Caesar also declared that Hyrcanus II and his sons would be allies and friends of the Roman people ${ }^{62}$. In 42-41 Mark Antony named Phasael and Herod as joint tetrarchs under the ethnarch Hyrcanus II ${ }^{63}$. In 40, Herod in Rome received the support of Octavian and Antony, and was appointed king of Judea by the Senate ${ }^{64}$.

As this period of Jewish history shows, leadership roles such as high priest and king (and even prophet) could be clearly distinguished, and when a leader claimed to be both high priest and king, such claims did not go unnoticed; moreover, when the Roman Senate finally confirmed Herod the Great as king of Judea, it was no small matter.

Roman sensitivities over the use of the title "king" ( $\beta \alpha \sigma i \lambda \varepsilon v$ c), especially as it related to imperial appointees in Judea, are also evident during the early Empire, for example, in Augustus's decision to name Archelaus ethnarch of Judea rather than king, as Herod had specified in his will, and to assign Philip and Antipas the title "tetrarch" ${ }^{65}$. Several years elapsed before Gaius, at the beginning of his reign (37-41), appointed Agrippa I king ( $\beta a \sigma \iota \lambda \varepsilon v$ c), assigning him control of the tetrarchies of Philip and Lysanias ${ }^{66}$. As a result of this imperial decision, Agrippa became the first Herodian after Herod the Great to bear the title "king"67. Moreover, Herod Antipas's ambition to be promoted from tetrarch to king, apparently egged on by his wife Herodias, proved to be his downfall ${ }^{68}$. As punishment for this insolent gesture, Gaius exiled them both ${ }^{69}$.

Taking into account this historical framework, mostly reported by Josephus, enriches the social-political context in which Matthew sets the story of Jesus. For

${ }^{59}$ B. J. 1.120-122; A. J. 14.4-7. See: Schürer E. The History of the Jewish People in the Age of Jesus Christ (175 B. C. - A. D. 135): in 3 vols / ed. by G. Vermes et al.; rev. ed. Edinburgh: T\&T Clark, 1973-1987. Vol. 1. P.234, n. 2.

${ }^{60}$ B. J. $1.153,169-170$.

${ }^{61}$ A. J. 14.143-148, 190-212. R. Marcus, LCL 7:523 n. f, notes that Caesar appointed Hyrcanus both high priest and ethnarch, according to the decrees cited in A. J. 14.190-212, further asserting, "by the Jews he seems to have been called king", citing A. J. 14.157, 172.

62 A. J. 14.194-195.

${ }^{63}$ B. J. 1.243-244; A. J. 14.324-326. R. Marcus, LCL 7:621 n. i, says "This (with the parallel

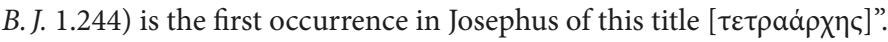

${ }^{64}$ B. J. 1.282-285; A. J. 14.379-389; similarly, Strabo, Geogr. 16.675; Appian, Bell. civ. 5.75; Tacitus, Hist. 5.9 (references, Marcus, LCL 7:651 n. h).

65 B. J. 2.93-94; A. J. 17.317-320.

${ }^{66}$ B. J. 2.181; A. J. 18.237; Philo, Flacc. 25; Legat. 324-326.

${ }^{67}$ On Agrippa I's appointment as king in 37, see: Schwartz D. R. Agrippa I (Texts and Studies in Ancient Judaism 23). Tübingen: Mohr Siebeck, 1990. P. 60.

${ }^{68}$ B. J. 2.182-183; A. J. 18.240-255.

${ }^{69}$ According to B. J. 2.183, they were exiled to Spain, although A. J. 18.252 reports Lyons in Gaul as their place of exile. See: Schwartz, Agrippa I, 5. 
one thing, this broader understanding of the way in which kingship was understood during the Hasmonean period, and subsequently in the early Empire, sets Matthew's portrait of Jesus as a royal figure, as the legitimate heir of the House of David, into bold relief. Given the way in which Rome is reported to have responded to episodic uprisings led by would-be kings, prophets, and the like, it is understandable why a figure whom Matthew explicitly designates "Messiah", "Son of David", "prophet", and "Son of Man", could be mocked and eventually executed under the ironic title "King of the Jews". As this brief survey shows, claiming the title "king" or even aspiring to it, much less being assigned that title officially, were politically and socially consequential actions, not only for the individual but also for his followers.

\section{Philo's De vita Mosis}

Now that we have surveyed some aspects of Second Temple Judaism that need to be taken into account when interpreting the Gospel of Matthew, we can return to our original question: To what section of the Table of Contents of Jewish writings from the Second Temple Period would the Gospel of Matthew belong? The answer is fairly clear: those writings that focus on the life, teachings, and accomplishments of a single individual. And in this respect, Philo's short treatises on the patriarchs Abraham and Joseph and his longer two-volume work De vita Mosis, would be the closest literary analogues ${ }^{70}$. While it would be profitable to compare Matthew with each of these three writings, I will concentrate on De vita Mosis ${ }^{71}$.

Although the position of De vita Mosis within the larger Philonic corpus is disputed, it is best understood as a work written mainly for outsiders, which introduces Philo's Exposition of the Law; and which is followed by De Opificio Mundi, a treatise arguing that the cosmos and the Law of Moses are harmonious. Then follow biographical treatments of the partriarchs Abraham (and some non-extant essays on other patriarchs) and Joseph, showing how the patriarchs

${ }^{70}$ In Feldman L.H., Kugel J.L., Schiffman L.H. (eds). Outside the Bible, the section titled "Interpretive Texts Centering on Biblical Figures" includes the following texts: Life of Adam and Eve, 1 Enoch, Apocalypse of Abraham, Melchizedek, Aramaic Levi Document, Visions of Amram, Song of Miriam, Apocryphon of Joshua, The Vision of Samuel, Pseudo-Ezekiel, The Apocryphon of Ezekiel, The Letter of Jeremiah, 1 Baruch, 2 Baruch, 3 Baruch, Prayer of Nabonidus, and 4 Ezra. One might also think of the Testaments of the Twelve Patriarchs and the Lives of the Prophets in a similar category. While each of these writings relates to particular individuals, they do so in different ways. They may report various traditions that have gathered around the name of an individual such as Enoch, Abraham, or Ezra; or wisdom traditions associated with scribal figures such as Baruch. But these writings do not conform to the genre ßioc, even if it is loosely defined, in which an author purports to rehearse the details of someone's life, beginning with his birth and concluding with his death.

${ }^{71}$ See: Feldman L. H. Philo's Portrayal of Moses in the Context of Ancient Judaism (Christianity and Judaism in Antiquity 15). Notre Dame: University of Notre Dame Press, 2007; Niehoff M. R. On the Life of Moses // Feldman et al. Outside the Bible. Vol. 1. P.959-988; also: Birnbaum E. On the Life of Abraham // Ibid. P.916-950; Burridge R. What Are the Gospels? P. 124-128, includes Philo's De vita Mosis among the five examples of early Graeco-Roman ßiol. 
embodied the Mosaic law before it was given. Next comes systematic exposition of the Law, beginning with the treatise De Decalogo, followed by four books of exposition De specialibus legibus, concluding with two treatises De virtutibus and De praemiis et poenis. The other major sections of Philo's works include The Allegorical Commentary, with a three-volume introductory work Legum allegoriae, which covers Gen 2:1-3:19, followed by seventeen separate treatises, each devoted to a specific section of Genesis, which cover Gen 3:24-31:21; and Quaestiones et solutiones in Genesin 1-4 and Quaestiones et solutiones Exodum 1-2, which cover Gen 2:4-28:9 and Exod 6:2-30:10 respectively ${ }^{72}$.

Philo's literary aim is made explicit from the outset: He intends to write "the

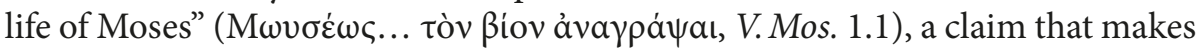
the title of the work entirely appropriate: ПEPI TOY BIOY $\mathrm{M} \Omega \Upsilon \Sigma \mathrm{E} \Omega \Sigma^{73}$. Acknowledging that Moses's legislation is widely known, Philo concedes that "the

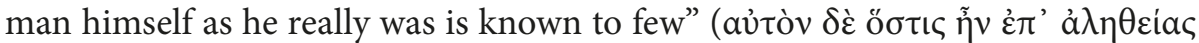

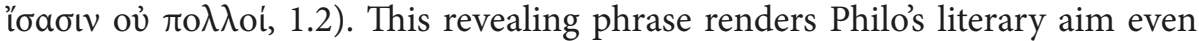
more explicitly. Rather than sketching certain external features of Moses's life that would surface, say, in a chronological rehearsal of events, Philo wants to probe more deeply in order to portray Moses as he truly was. As the unfolding narrative makes clear, Philo thinks this deeper understanding of Moses can be achieved only if one grasps his multi-faceted significance. While Moses's fame as a lawgiver may be widely known, this singular achievement, Philo argues, does not do justice to the other dimensions of his life, most notably his role as sovereign leader of the Jewish people (to which Book 1 is devoted), but also his priestly and prophetic leadership.

Book 1 of De vita Mosis can be read as a form of "rewritten Bible", based mainly on Exodus and Numbers, with occasional excursuses prompted by the biblical narrative and yet diverging freely from $\mathrm{it}^{74}$. For the most part, the ep-

${ }^{72}$ In my construal of The Exposition of the Law I follow: Sandmel S. Philo of Alexandria: An Introduction. Oxford: Oxford University Press, 1979. P. 47-76; similarly: Runia D. Philo of Alexandria: On the Creation of the Cosmos according to Moses // Philo of Alexandria Commentary. Series 1. Leiden: Brill, 2001. P. 1-4; for a slightly different view, see: Royse J.R. The Works of Philo // The Cambridge Companion to Philo / ed. by A. Kamesar. Cambridge: Cambridge University Press, 2009. P. 32-64.

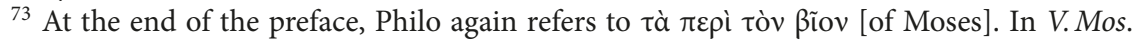

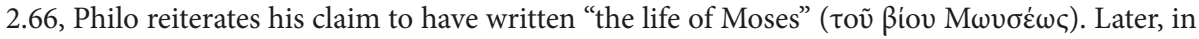
his discussion of humanity ( $\varphi \iota \lambda \alpha v \theta \rho \omega \pi i \alpha)$ as a virtue, Philo recalls the "two treatises in which

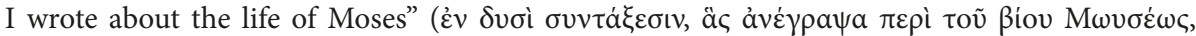
Virt. 52).

${ }^{74}$ See: Potter J. Rewriting Moses and Mark: The Composition of Luke's Gospel in Light of Rewritten Scriptural Narratives. PhD dissertation. Emory University, 2019, with extensive bibliography. - As Potter reports, the expression "rewritten Bible" was coined by: Vermès G. Scripture and Tradition in Judaism: Haggadic Studies (Studia post-biblica 4). Leiden: Brill, 1961. Among numerous publications, see: Crawford S. W. Rewriting Scripture in Second Temple Times (Studies in the Dead Sea Scrolls and Related Literature). Grand Rapids: Eerdmans, 2008; Zsengellér J., (ed.). Rewritten Bible after Fifty Years: Texts, Terms, or Techniques? A Last Dialogue with Geza Vermes (Supplements to the Journal for the Study of Judaism). Leiden: Brill, 2014. P. 166. In Feldman et al. Outside the Bible, the section including notable examples of "rewritten 
isodes Philo chooses to report are directly related to Moses, and just as in the biblical account, they highlight Moses's leadership role as it is reflected in those stories. One obvious exception is the fairly lengthy account of Balak and Balaam (1.263-293), in which Moses plays no role. But there are some glaring omissions such as the giving of the law at Sinai (Exod 20-25), and these are hard to explain. Even when Philo discusses Moses as legislator in Book 2, he alludes only briefly to the Sinai epiphany (2.69-70).

There are some other organizational oddities. While De vita Mosis is notable for the way in which it is organized around the four roles of king, legislator, priest, and prophet, this fourfold schematization is not clear from the outset. Nowhere in the opening preface (1.1-4) does Philo preview the work using these four categories. In fact, he does not mention them explicitly until the beginning of Book 2, when he lays out the details of this framework in the preface (2.1-7). This comes as a surprise, since the concluding paragraph of Book 1 reports that, Philo, having "told the story of Moses's actions in his capacity as king", will next deal with the powers Moses displayed "as high priest and legislator" (1.334). Somewhere between writing the conclusion to Book 1 and the opening preface of Book 2, Philo apparently decided to include prophecy as a fourth interpretive category. Perhaps this occurred because he had already singled out several instances of Moses's prophetic powers in Book $1^{75}$.

While the retrospective conclusion to Book 1 claims that it told "the story of Moses's actions in his capacity of king", the motif of Moses as king is introduced only gradually as the narrative unfolds. In reporting Moses's early life, Philo says that he was brought up as a prince ( $\left.\beta \alpha \sigma \iota \lambda_{\iota \kappa \tilde{\eta} \varsigma}\right)$ in Egypt (1.8), and that he received the nurture and service fit for a prince ( $\beta a \sigma \iota \lambda \iota \kappa \tilde{\eta} \varsigma, 1.20)$. It was widely expected

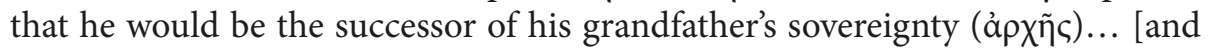

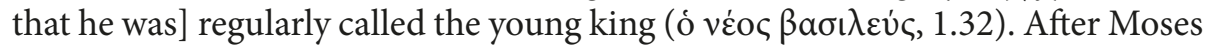
killed the Egyptian, his detractors accuse him of wanting to take the throne ( $\tau \tilde{\eta} \varsigma$ à $\rho \chi \tilde{\eta} \varsigma)$ from his grandfather. They complain that "he is eager to get the kingship ( $\beta a \sigma i \lambda \varepsilon i a \varsigma)$ before the time comes" (1.46). The kingship motif especially surfaces in the report of Moses's becoming a shepherd in Arabia, when Philo asserts that shepherding is the best training for kingship: "[he] received his first lesson in the command of others; for the shepherd's business is a training-ground and a preliminary exercise in kingship for one who is destined to command the herd

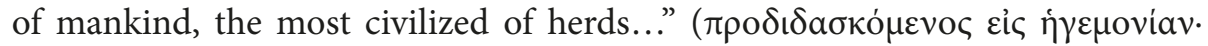

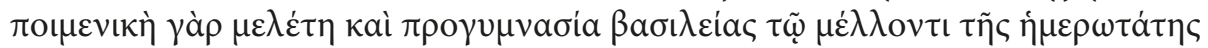
$\left.\tau \tilde{\omega} \nu \dot{\alpha} v \theta \rho \dot{\omega} \pi \omega \nu \dot{\varepsilon} \pi \_\tau \tau \alpha \tau \tilde{\varepsilon} v \dot{\alpha} \gamma \dot{\varepsilon} \lambda \eta \varsigma, 1.60\right)$. Philo cites the adage that kings are "shepherds of their people" (1.61), and while he does not cite a source, he may

Bible" such as The Genesis Apocryphon and Jubilees is titled "Sustained Biblical Commentaries: Retellings and Pesharim".

75 See: V.Mos. 1.57, in which Moses, while chastening the Arabian shepherds who were harassing the seven young maidens, "grew inspired and was transfigured into a prophet". Similarly, 1.175, during the exodus, Moses predicts the defeat of Egyptians; 1.201, during the manna episode, Moses" possessed divine inspiration, spoke these oracular words"; 1.210, under inspiration, Moses struck the rock. 
be echoing Ezekiel's description of the leaders of Israel as shepherds (Ezek 34), a metaphor that reflects the widespread association of shepherds with kings in the ancient Near East.

The kingship motif achieves special prominence about midway through Book 1, when Philo diverges from the biblical account to provide an excursus on Moses's moral development (1.148-162). His explicit use of kingship language

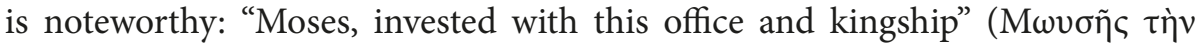

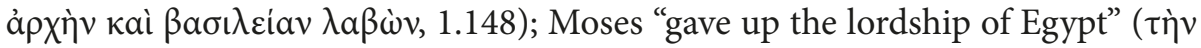

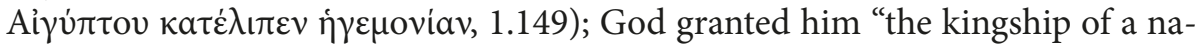

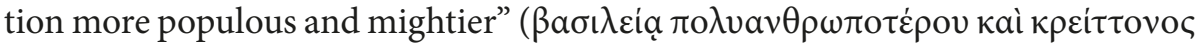

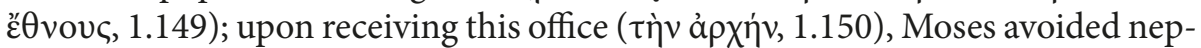
otism; cared only for his subjects; eschewed riches, preferring instead the wealth of nature; refused excess, displaying moderation instead; sought only to pur-

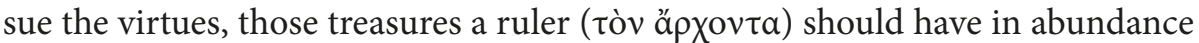
(1.153-154). Accordingly, God granted Moses dominion over nature, thereby making him a world citizen (1.157). As God's true partner and collaborator, Moses was given the same title, being made "god and king of the whole nation"

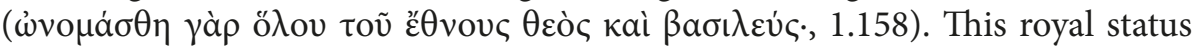
enabled Moses to enter God's exclusive space - "the unseen, invisible, incor-

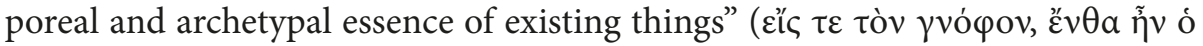

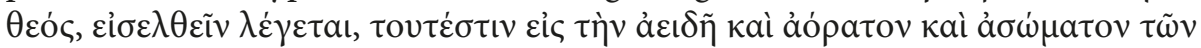

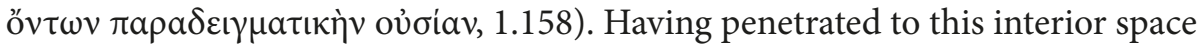
of God, Moses exemplifies the true philosopher and in turn becomes a model for others, especially other rulers: "in himself and his life displayed for all to see, he has set before us, like some well-wrought picture, a piece of work beautiful

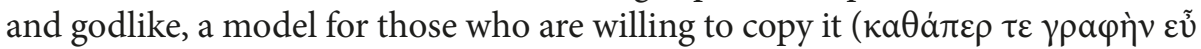

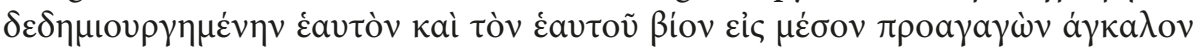

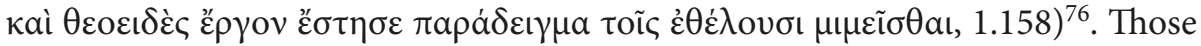
who strive to imprint this image of Moses on their souls are truly blessed. When a ruler $(\dot{\eta} \gamma \varepsilon \mu \dot{\omega} v)$ is profligate, so will his subjects be (1.160). At the end of this

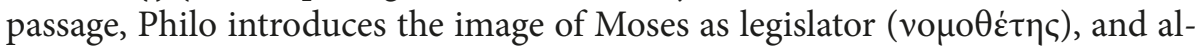
though this was his future destiny, already at this early stage of his career he was

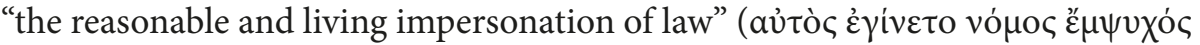

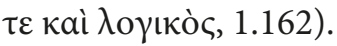

In Book 2, the preface (2.1-7) briefly summarizes the first book, which dealt with "the birth and nurture of Moses" and "with his education and career as a ruler" (ả $\rho \chi \tilde{\eta} \varsigma)$. After giving a compact review of the events covered in Book 1, Philo explains why the four discrete roles are necessary requirements for leadership. Of the four, kingship remains the foundational category for Philo, with the other three roles seen as requisite ancillary functions. A king, especially the

${ }^{76}$ On V.Mos. 1.158, see: Holladay C. R. THEIOS ANER // Hellenistic-Judaism: A Critique of the Use of This Category in New Testament Christology (Dissertation Series - Society of Biblical Literature 40). Missoula: Society of Biblical Literature, 1977. P. 108-129; for further treatment of this passage, see: Litwa M.D. The Deification of Moses in Philo of Alexandria // The Studia Philonica Annual: Studies in Hellenistic Judaism. 2014. Vol. 26. P. 1-27. 
philosopher king, must be a worthy legislator, an exemplary religious leader, i. e., priest, and someone gifted with divine inspiration, i. e., a prophet.

One of the striking features of Book 2 is the disproportionately brief treatment of Moses as legislator (2.8-65) - roughly half the length (14 pages) of each section devoted to his priestly and prophetic roles (28 pages each $)^{77}$. After brief mention of the virtues required of an exemplary legislator, Philo argues for the enduring validity and permanence of Moses's laws, which have been widely acknowledged. As proof of this universal acclaim, he adduces Ptolemy II Philadelphus's initiative in requesting a Greek translation of the Hebrew Scriptures (2.26-44). Rather than giving a detailed rehearsal of Moses's legislative genius, Philo insists that it is reflected in the two-fold organizational structure of the Pentateuch: the historical part reporting the creation of the world and early Israelite history, while the commands and prohibitions specify which behaviors are acceptable. His internal logic is clear: ethics is grounded in cosmology. The story of Noah is cited as an example.

All three sections of Book 2 consistently display two features also found in Book 1: a strong moralistic cast and Philo's penchant for symbolic or allegorical exegesis. Philo begins the legislative section by noting the virtues required of a successful legislator (2.8-25).

The priestly section (2.66-186) begins by underscoring the paramount importance of piety ( $\varepsilon \dot{v} \sigma \varepsilon \beta \varepsilon i \alpha$ ), and reporting Moses's moderation and moral purity in his preparation for receiving the divine oracles (2.66-70). Similarly, the third section begins with Philo's assertion that Moses was "a prophet of the highest quality" (2.187), and that God's prophetic oracles are "signs of the di-

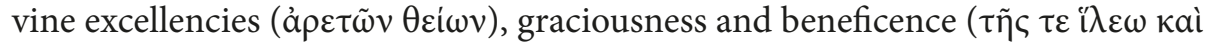

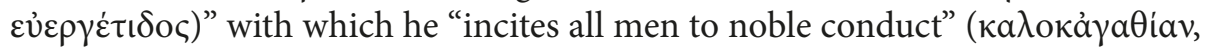
189).

Just as his allegorical exegesis surfaces in his treatment of Moses as king in Book $1^{78}$, it is especially frequent in the section on Moses as high priest in Book 2 (2.66-186). Explaining the five pillars in the propylaeum of the tabernacle prompts Philo to expatiate on the five human senses and how the configuration of the tabernacle with its inner and outer courts symbolizes the human being who consists of both "mind" and "sense" (2.81-82). His description of the material and length of the tabernacle curtains triggers numerological reflections on the numbers four, ten, twenty-eight, and forty, the number of weeks a baby resides in the womb (2.84). The four colors of thread used to weave the curtains symbolize the four elements earth, water, air, and fire, a reminder of God's creative role (2.88). The ark of the covenant symbolizes God's gracious power, which enables humans to be grateful rather than prideful (2.96). The cherubim, representing recognition and full knowledge, symbolize the two hemispheres above

77 Some think Philo's treatment of Moses as legislator was originally longer and that a section has dropped out; others think that Philo abbreviated it because he gives fuller treatment to the Mosaic legislation elsewhere. See Colson's note on $\$ 65$ in the LCL Appendices, p. 606-607.

${ }^{78}$ E. g., the burning bush episode (1.67-70) and the Elim episode (1.188-190); Philo's allegorizing is especially strong in De Abrahamo and to a lesser extent in De Iosepho. 
and below the earth, along with the creative and kingly potencies (2.98-99). The altar of incense is a symbol of gratitude (2.101), while the candlestick with its various branches symbolizes the luminaries and planets (2.103). The position of the table of shewbread, as well as the bread and salt on it, also illustrate how food comes from heaven and earth (2.104). The crown displayed on the high priest's ephod signifies the four letters of the tetragrammaton (2.115). The high priest's vestments, with all of their intricate decorations, have manifold symbolic significance, including heaven, the zodiac, and human reason. The cumulative effect of all these clothing details is to signal that, when the high priest enters the innermost sanctuary, he takes the whole universe with him - the high priest is a "little world", a microcosm (2.117-135). The laver is a symbol of purity (2.138139), and the twelfth rod with Aaron's name on it, which becomes a budding plant, shows that the nut is a symbol of perfect virtue, and illustrates that the four virtues justice, temperance, courage, and wisdom are available to those who devote themselves to austerity and hardship, i. e., to continence and self-restraint (2.181-186).

What becomes especially clear in this elaborate rehearsal of the tabernacle, its furnishings, dimensions, and fixtures, along with the detailed treatment of the decorative elements of the high priest's vestments is that allegorical interpretation, rather than being seen as separate from Philo's moralistic emphasis, is in fact one of the main hermeneutical strategies through which his moralizing occurs. For Philo, allegory serves his moral interests. This applies not only to Moses himself but also to his legislation, which, throughout, serves as the means by which the reader of the Bible or the practicing Israelite can access the moral truths embedded within the Mosaic legislation. Working with the Stoic assumption that the individual's ultimate goal is to conform to one's moral will to the cosmic will of the universe, Philo shows how the Mosaic law is critical to achieving this end.

While Philo's rehearsal of Moses's priestly role tends to follow the order of events in the biblical narrative, his treatment of Moses as prophet displays a different organizational structure (2.187-291). His overall aim in this section is to show that Moses "was a prophet of the highest quality" (2.187). In his preliminary discussion, Philo conceives of three types of divine utterances: (1) those in which the main emphasis is on God's own initiative - utterances spoken directly by God to an interpreter; (2) utterances that occur when God answers a question the prophet has asked, thus in which God and the prophet collaborate; and (3) those utterances in which the experience of the prophet under divine inspiration is the most prominent element. The first type of divine utterance Philo does not discuss. In a class to itself, it is beyond praise, "too great to be lauded by human lips" (2.191). Philo explains the other two types by adducing four specific examples.

Moses receives a prophetic oracle, or a "divine ruling" from God, in four exemplary cases: (a) capital punishment for someone who blasphemes God (2.192-208; cf. Lev 24:10-16); (b) capital punishment for violating the Sabbath (2.209-220; cf. Exod 31:14; 35:2; Num 15:32-36); (c) resolving the conflict that 
arises when the demands of mourning and funeral rites conflict with the rules for Passover observance (2.221-232; cf. Num 9:1-14); and (d) clarifying the laws of inheritance in special situations, e.g., when a man dies without any male heirs (2.233-245; cf. Num 27:1-11).

As for oracles received by Moses under divine inspiration, Philo adduces four examples: (a) predicting the parting of the Red Sea and the defeat of the Egyptians (2.246-257; cf. 1.175; Exod 14); (b) praying for manna, especially in obtaining directions for receiving it on the Sabbath (2.258-269; cf. 1.201; Exod 16:4-30); (c) invoking the slaughter of the Golden Calf idolaters (2.270-274; Exod 32); and (d) destruction of the priestly rebels and their companions (the Korah rebellion; 2.275-287; Num 16).

Having cited specific cases of Moses's prophetic activity in each of the aforementioned categories, Philo shifts to the account of Moses's death, which he presents as the culminating prophecy of his career. Philo is aware of the main interpretive problem: The account of Moses's death in Deut 33-34 would appear to imply that it was written post-mortem. Instead, Philo presents it as a case of Moses's prophesying his own mysterious departure.

As with Philo's treatment of Moses's other three roles, here also his moralistic interests are clearly on display. Moses is the "holiest of men ever yet born" (2.192). Blaspheming is seen as a "monstrous violation of the moral law" (2.198). Deciding on the appropriate punishment for a blasphemer is a matter of justice ( $\delta$ ikn, 2.200). Reaching this decision, Moses is praised as "the wisest of men", who has drunk from the undiluted "wine of wisdom" (2.204). The Sabbath should be reserved for the exclusive pursuit of wisdom $(2.211,215)$; accordingly, the "places of prayer throughout the cities [are] schools of prudence and courage and temperance and justice and also of piety, holiness and every virtue by which duties to God and men are discerned and rightly performed" (2.216). In seeking meaningful ways to resolve conflicts involving observance of the Law, Moses honors God's truth and justice (2.237). Those who punished the Golden Calf idolaters were accounted as "the noblest of heroes" (2.274). In dealing with the internal rebellion among the priests, Moses, "though the mildest and meekest of men, was so spurred by righteous anger by his passionate hatred of evil that he besought God to turn His face from their sacrifice" (2.279). Moses insists that he does not lie (2.280).

\section{The Gospel of Matthew and Philo's De vita Mosis: A Comparison}

The Gospel of Matthew is roughly two-thirds the length of Philo's De vita $M_{o s i s}{ }^{79}$. One of the most obvious differences in the two works is that, while De vita Mosis is composed in the first-person ${ }^{80}$, the implied author of Matthew operates as an ominisicent narrator. While De vita Mosis is explicitly identified as a ßícs, Matthew gives no indication of its literary genre within the narrative. Only

${ }^{79}$ According to TLG, Matthew contains 18,338 words, while De vita Mosis contains 31400 words.

${ }^{80}$ See: V.Mos. $1.1,4-5 ; 2.3,8$. 
in the title, which was probably ascribed to the work in the second century, is

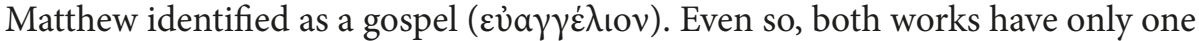
main character: Jesus Christ in Matthew and Moses in De vita Mosis. The main difference between the two works is that one treats a figure from the distant past, the other a relatively recent figure. Nevertheless, this focused attention on one main character means that both works should be read as $\beta$ iol.

While the Old Testament figures prominently in the composition of each work, it does so in different ways. Much of De vita Mosis consists of "rewritten Bible" in which OT stories are retold through summary or paraphrase, often with considerable literary license comparable to later forms of rabbinic Haggadah. Although Philo's hermeneutical method in De vita Mosis is not full-scale allegory comparable to what is found in Legum Allegoriae, it does exhibit a consistent tendency to identify the symbolic significance of various features of the biblical text. By contrast, Matthew does not display interest in allegory or explicit symbolism comparable to what is found in De vita Mosis. Probably the closest Matthew comes to employing allegory is Jesus's interpretation of the Parable of the Sower (Matt 13:18-23). Implicit allegory or symbolism may be reflected in Matthew's Birth and Infancy Narrative, which would prompt an informed OT reader to see a resemblance between Herod's threats against the infant Jesus and Pharaoh's slaughter of the Hebrew children; or the Parable of the Wicked Tenants (Matt 21:33-46), when the wicked tenants slay the landowner's son (21:39), but Matthew's version is more muted than the mention of the "beloved son" in Mark 12:6 and Luke 20:13. For all its dependence on the OT as the main source text, De vita Mosis nowhere exhibits interest in Matthew's use of promise-fulfillment as a hermeneutical scheme. Nothing close to Matthew's numerous "fulfillment quotations" is found in De vita Mosis.

In terms of the overall story, both Matthew and De vita Mosis begin their stories by devoting attention to the birth and infancy of their respective heroes; moreover, they conclude their narratives by reporting how each figure died. But the proportions are quite different, with Matthew's Passion Narrative occupying several chapters (chs. 26-27, ca. $12 \%$ of the narrative), while the death of Moses is treated with relative brevity in De vita Mosis (ca. two pages in LCL; 2.288-291). Their respective arrangement of material reflects the two main options used by ancient biographers: Matthew follows a roughly chronological arrangement, while De vita Mosis opts for a topical arrangement ${ }^{81}$. In some respects, Matthew's arrangement is topical, just as parts of De vita Mosis more or less follow the biblical timeline. Even so, the means by which each work portrays its main character differs rather substantially. In Matthew, the character of Jesus is portrayed episodically. The narrative consists mainly of stories or episodes in which John the Baptist and his successor Jesus figure as the main character with which other characters interact, either positively or negatively. This is especially true in the narrative portions of Matthew, including the Passion Narrative, and the events

${ }^{81}$ On the use of chronological and topical arrangement, see: Burridge R. What are the Gospels. P. 115, 200-202. 
pertaining to Easter. Sayings material is interwoven into these episodes, but is most conspicuously collected in Matthew's five main discourses (chs. 5-7, 10, $13,18,23-25)$. This same episodic arrangement is true to some extent in De vita Mosis, but not in the same way. For one thing, episodes featuring Moses figure differently in each of the four portrayals. They are especially prominent in Philo's portrayal of Moses as king in Book 1, to some extent in the priestly section (2.66-186), but scarcely at all in the legislative section (2.8-65), and in a highly schematized way in the prophetic section (2.187-291).

Another way in which the two works can be compared profitably is their respective use of explicit encomium. In De vita Mosis Philo repeatedly praises Moses with superlatives: he is the "greatest and most perfect of men" (1.1); "the holiest of men ever yet born" (2.192); "great in everything" (2.211); "the mildest and meekest of men" (2.279). The closest Matthew's narrator comes to using such bold encomiastic language is the opening verse: "An account of the genealogy of Jesus the Messiah, the son of David, the son of God" (1:1). Here, the narrator's own sentiments are clearly expressed, but this verse is remarkable for being exceptional. To be sure, bold claims are made about Jesus in Matthew, but these tend to occur on the lips of characters within the story, e. g., the Christological titles in the Birth and Infancy Narrative $(1: 20-21,23)$; the heavenly voice at Jesus's baptism (3:17) and the Transfiguration (17:5); the demoniacs (8:29); the two blind men $(9: 27 ; 20: 31)$; John the Baptist's question (11:2); Peter's confession (16:16); Jesus's prediction of his death $(17: 22 ; 20: 18)$, and, of course, the collection of Son of Man sayings throughout the Gospel; the question about the Son of David (22:41-45); Pilate's question (26:63-64); and the centurion (27:54).

The two narratives also differ in the ways in which the moral character of the central figure is portrayed. In De vita Mosis, Philo's moralistic emphasis is consistent and explicit. In numerous ways, he depicts Moses as the embodiment of philosophical virtue, both in the ways he behaves and in the legislation he formulates. Philo employs conventional moral language, such as the four cardinal virtues or comparable qualities, in describing Moses and his legislation, even insisting that Jewish synagogues are schools in which the virtues are taught. Throughout De vita Mosis Philo portrays Moses as the supreme teacher of virtue who himself epitomizes the virtues. As such, he is a moral paradigm for everyone, especially other kings and leaders. In Matthew there is also a pervasive didactic dimension. Jesus's teaching is showcased in the five, highly formalized discourses, as well as in numerous episodes in which pronouncements and other chreia figure prominently. But the moralistic dimension of the portrait of Jesus in Matthew is indirect rather than direct. One can deduce Jesus's passion for such virtues as justice, forgiveness, and wisdom from the Sermon on the Mount, but these claims are implicit rather than explicit; at least, they are not as explicit as Philo's claims about Moses in De vita Mosis. 


\section{Conclusion}

Although the Gospel of Matthew is sometimes read as an early Christian writing, whose distinctiveness reflects the perceived uniqueness of its central figure Jesus Christ, it can be read profitably as a Jewish writing that emerged within the context of Second Temple Judaism ${ }^{82}$. The literary achievement represented by this Gospel, rather than being exceptional, should be seen as part of a broader literary movement in which Jewish writers had participated for at least a century, if not longer. That Matthew can be confidently dated in the last quarter of the first century CE means that it can be related effectively to the social-political context of Palestinian Judaism during the Early Empire. The numerous Jewish writings that are preserved from this period provide valuable literary parallels as well as perspectives on major trends of thought and movements such as those related to various would-be leaders and messianic pretenders. Such prolific writers as Philo and Josephus also provide abundant testimony about historical figures and events, and this valuable evidence must also be taken into account in our interpretations of Matthew. Close comparisons between Matthew and specific Jewish writings such as Philo's De vita Mosis can be profitable in detecting similarities of literary genre and purpose but also in identifying distinctive features of each writing. Further literary comparisons beyond the one attempted in this paper would be profitable, as would more focused efforts to relate various dimensions of Matthew such as its eschatology or apocalyptic outlook to the multifaceted literature of this period.

\section{References}

Broadhead E. K. (2017) The Gospel of Matthew on the Landscape of Antiquity (Wissenschaftliche Untersuchungen zum Neuen Testament 378). Tübingen, Mohr Siebeck.

Burridge R. (2004) What Are the Gospels? A Comparison with Graeco-Roman Biography. $2^{\text {nd }}$ ed. Grand Rapids, Cambridge, WM. B. Eerdmans Publishing Co.

Charles R. H. (1913) The Apocrypha and Pseudepigrapha of the Old Testament in English, in 2 vols. Oxford, Oxford University Press.

Charlesworth J.H. (1983-1985) The Old Testament Pseudepigrapha, in 2 vols. New York, Doubleday.

Cohen S. J.D. (2014) From the Maccabees to the Mishnah. $3^{\text {rd }}$ ed. Louisville, Westminster John Knox Press.

Collins A. Y., Collins J.J. (2008) King and Messiah as Son of God: Divine, Human, and Angelic Messianic Figures in Biblical and Related Literature. Grand Rapids, Wm. B. Eerdmans Publishing Co.

Collins J. J. (2005) Encounters with Biblical Theology. Minneapolis, Fortress Press.

${ }^{82}$ See: Broadhead E. K. The Gospel of Matthew on the Landscape of Antiquity (Wissenschaftliche Untersuchungen zum Neuen Testament 378). Tübingen: Mohr Siebeck, 2017; Overman J. A. Matthew's Gospel and Formative Judaism: The Social World of the Matthean Community. Minneapolis: Fortress Press, 1990; Runesson A. Divine Wrath and Salvation in Matthew: The Narrative World of the First Gospel. Minneapolis: Fortress Press, 2016; Sim D. C. The Gospel of Matthew and Christian Judaism: The History and Social Setting of the Matthean Community (Studies of the New Testament and Its World). Edinburgh: T\&T Clark, 1998. — I am grateful to A. Culpepper for these references. 
Collins J. J. (2010) The Scepter and the Star: Messianism in Light of the Dead Sea Scrolls. $2^{\text {nd }}$ ed. Grand Rapids, Wm. B. Eerdmans-Lightning Source.

Crawford S.W. (2008) Rewriting Scripture in Second Temple Times (Studies in the Dead Sea Scrolls and Related Literature). Grand Rapids, Eerdmans.

Davies W.D., Allison D.C. (1988-1997) A Critical and Exegetical Commentary on the Gospel According to Saint Matthew, in 3 vols (International Critical Commentary). Edinburgh, T\&T Clark.

Feldman L.H. (2007) Philo's Portrayal of Moses in the Context of Ancient Judaism (Christianity and Judaism in Antiquity Series 15). Notre Dame, University of Notre Dame Press.

Feldman L. H., Kugel J. L., Schiffman L.H. (eds) (2013) Outside the Bible: Ancient Jewish Writings Related to Scripture, in 3 vols. Philadelphia, Jewish Publication Society.

Holladay C. R. (1977) “THEIOS ANER”, in Hellenistic-Judaism: A Critique of the Use of This Category in New Testament Christology (Dissertation Series - Society of Biblical Literature 40). Missoula, Society of Biblical Literature.

Holladay C.R. (2016) Acts: A Commentary (New Testament Library). Louisville, Westminster John Knox Press.

Horsley R. A., Hanson J.S. (1988) Bandits, Prophets, and Messiahs: Popular Movements in the Time of Jesus. San Francisco, Harper Collins.

Kamesar A. (ed.) (2009) The Cambridge Companion to Philo. Cambridge, Cambridge University Press.

Kraft R. A., Nickelsburg G. W.E. (eds) (1986) Early Judaism and Its Modern Interpreters. Atlanta, Scholars Press.

Kümmel W.G., Christian Habicht Ch., Kaiser O., Plöger O., Schreiner J., Lichtenberger H. (Hrsg.) (1973-1999) Jüdische Schriften aus hellenistisch-römischer Zeit, in 6 Bdn. Gütersloh, Gütersloher Verlagshaus.

Litwa M.D. (2014) "The Deification of Moses in Philo of Alexandria", in The Studia Philonica Annual: Studies in Hellenistic Judaism, vol. 26. pp. 1-27.

Luz U. (2001-2007) Matthew, in 3 vols, transl. by J. E. Crouch. Minneapolis, Fortress Press.

Moule C. F. D. (1981) The Birth of the New Testament. $3^{\text {rd }}$ ed. London, Adam and Charles Black.

Neusner J., Green W. S., Frerichs E. S. (eds) (1987) Judaisms and Their Messiahs at the Turn of the Christian Era. Cambridge, Cambridge University Press.

Niehoff M. R. (2012) "Philo and Plutarch as Biographers: Parallel Responses to Roman Stoicism", in Greek, Roman \& Byzantine Studies, vol. 52, pp. 361-392.

Oegema G. S. (1998) The Anointed and His People: Messianic Expectations from the Maccabees to Bar Kochba (Journal for the study of the pseudepigrapha: Supplement series 27). Sheffield, Bloomsbury T\&T Clark.

Overman J. A. (1990) Matthew's Gospel and Formative Judaism: The Social World of the Matthean Community, Minneapolis, Fortress Press.

Royse J. R. (2009) "The Works of Philo", in The Cambridge Companion to Philo, ed. by A. Kamesar. Cambridge, Cambridge University Press, pp. 32-64.

Runesson A. (2016) Divine Wrath and Salvation in Matthew: The Narrative World of the First Gospel. Minneapolis, Fortress Press.

Runia D. (2001) "Philo of Alexandria: On the Creation of the Cosmos according to Moses", in Philo of Alexandria Commentary. Series 1. Leiden, Brill.

Sanders E. P. (1994) Judaism: Practice and Belief, 63 BCE - 66 CE. London, Trinity Pr Intl.

Sandmel S. (1979) Philo of Alexandria: An Introduction. Oxford, Oxford University Press.

Schäfer P. (2003) The History of the Jews in the Greco-Roman World. London, Routledge.

Schürer E. (1973-1987) The History of the Jewish People in the Age of Jesus Christ (175 B. C. A.D. 135), in 3 vols, ed. by G. Vermes et al., rev. ed. Edinburgh, T\&T Clark.

Schwartz D. R. (1990) Agrippa I. (Texts and Studies in Ancient Judaism). Tübingen, Mohr Siebeck.

Schweitzer A. (2001) The Quest of the Historical Jesus. First Complete Edition, ed. by J. Bowden. Minneapolis, Fortress Press. 
Sim D. C. (1998) The Gospel of Matthew and Christian Judaism: The History and Social Setting of the Matthean Community (Studies of the New Testament and Its World). Edinburgh, T\&T Clark.

Smallwood E. M. (1981) The Jews Under Roman Rule: From Pompey to Diocletian: A Study in Political Relations (Studies in Judaism in Late Antiquity 20). Leiden, Brill.

Stendahl K. (1967) The School of St. Matthew and Its Use of the Old Testament. $2^{\text {nd }}$ ed. (Acta Seminarii Neotestamentici Upsaliensis 20). Lund, Gleerup.

Vanderkam J.C. (1992) "Righteous One, Messiah, Chosen One, and Son of Man in 1 Enoch 37-71", in The Messiah: Developments in Earliest Judaism and Christianity, The First Princeton Symposium on Judaism and Christian Origins, ed. by J.H. Charlesworth. Minneapolis, Fortress Press.

Vermès G. (1961) Scripture and Tradition in Judaism: Haggadic Studies (Studia post-biblica 4). Leiden, Brill.

Zsengellér J. (ed.) (2014) Rewritten Bible after Fifty Years: Texts, Terms, or Techniques? A Last Dialogue with Geza Vermes (Supplements to the Journal for the Study of Judaism). Leiden, Brill.

Received: March 26, 2020

Accepted: April 23, 2020

Author's information:

Carl Roark Holladay - Professor, Elected Fellow of the American Academy of Arts and Sciences; theocrh@emory.edu

\section{Евангелие от Матфея в контексте иудаизма эпохи Второго Храма}

\section{К.Р. Холладей}

Школа теологии при Университете Эмори, США, 30322, Джорджия, Атланта, Дикки Драйв, 1531, Рита Энн Роллинз Билдинг

Для цитирования: Holladay C.R. The Gospel of Matthew within the context of Second Temple Judaism // Вопросы теологии. 2020. Т. 2, № 2. С. 341-367.

https://doi.org/10.21638/spbu28.2020.210

В статье анализируется Евангелие от Матфея в рамках широкой литературной традиции иудаизма эпохи Второго Храма. Еврейские сочинения, созданные на территории Израиля и в диаспоре с хасмонейского периода до времени ранней империи, позволяют рассмотреть Евангелие от Матфея в социальном, политическом и теологическом контексте. Анализ некоторых аспектов иудаизма эпохи Второго Храма, а именно мессианских ожиданий, апокалиптических движений и методов толкования Писания, способствуют пониманию того, как Матфей рассказывает историю Иисуса. В трактатах Филона и Иосифа можно проследить литературные параллели, а также выявить общие направления мысли, которые необходимо учитывать при интерпретации Евангелия от Матфея. То, как Матфей подчеркивает царский статус Иисуса, законного царя из дома Давидова, в определенной мере сопоставимо с тем, как вопрос о царской власти воспринимался в хасмонейский период. Мотив царской власти важен для «Жизни Моисея» Филона, в этом тексте Моисей рассматривается как царь, законодатель, священник и пророк. В результате сравнительного анализа автор ставит вопрос: можно ли отнести Евангелие 
от Матфея или даже остальные три канонических Евангелия к типичному собранию еврейских писаний?

Ключевые слова: библейские исследования, Новый Завет, Евангелие от Матфея, иудаизм Второго Храма, мессианство, апокалиптические движения.

Статья поступила в редакцию 26 марта 2020 г.

Статья рекомендована к печати 23 апреля 2020 г.

Информация об авторе:

Холладей Карл Роарк - проф., избранный член Американской академии искусств и наук; theocrh@emory.edu 


\section{Appendix: Outline of Philo, De vita Mosis}

\section{Book 1}

$1.1-4-$ Preface

$1.5-334-$ Moses as king (84 pp.)

1.5-17 - Birth and infancy (Exod 2:1-10)

1.18-33 - Moses's Egyptian upbringing, his precocity, and moral development

1.34-43 - Israelites under Egyptian bondage (Exod 2:14-25)

1.44-46 - Slaying the Egyptian (Exod 2:11-15a)

1.47-50 - Flight to Arabia, Moses's continuing moral development (cf. Exod 2:15b)

1.51-59 - Moses's intervention in the dispute between seven young maidens and shepherds, Moses's marriage (Exod 2:16-22)

1.60-62 - Moses becomes shepherd, training for kingship

1.63-84 - Burning bush, Moses's call, three signs (Exod 3:1-4:17)

1.85-95 - Moses's return to Egypt, signs contest (Exod 4:18-27; 5:22; 7:8-13)

1.96-146 - Ten plagues, some in different order (Exod 7-12:32)

1.147 - Summary description (Exod 12:33-42)

1.148-162 - Excursus: Moses as king and moral paradigm

1.163-180 - Departure from Egypt, pillar of cloud, Egyptian pursuit, parting the sea, choral celebration (Exod 13:17-15:21)

1.181-187 - Bitter water made sweet (Exod 15:22-26)

1.188-190 - Elim, slightly allegorized (Exod 15:27)

1.191-208 - Bread from heaven (Exod 16)

1.209 - Quails (Exod 16; Num 11:31-33)

1.210-211 - Water from rock (Exod 17:1-7; Num 20:1-13)

1.212-213 - Excursus on marvels of God and the universe

1.214-219 - Defeat of Phoenicians (Amalek) (Exod 17:8-16; cf. Deut 25:17-19)

1.220-236 - Sending spies (Num 13-14) [NB: Philo omits Exod 18 (Jethro); Sinai, giving of law, Exod 20-25]

1.237-238 - Summary - wanderings for 38 years

1.239-249 - Confrontation with kinsmen/Edom (Num 20:14-21)

1.250-254 - Defeat of Canaanite king Arad (Num 21:1-3)

1.255-257 - Discovery of spring (Num 21:16-18)

1.258-262 - Defeat of Sihon, king of Amorites (Num 21:21-32)

1.263-299 - Balak, Balaam (Num 22-24; cf. Num 31:16)

1.300-304 - Worship of Baal at Peor and incident of Midianite women (Num 25)

1.305-318 - Moses chooses Phinehas, who leads the conquest of Canaan (Num 31)

1.319-333 - Summary of wars fought east of Jordan (Num 32)

1.334 - Conclusion - "We have told the story of Moses's actions in his capacity of king" 
2.1-7 - Preface - Moses as the embodiment of four discrete roles: king, lawgiver, high priest, prophet

2.8-65 - Moses as legislator, with sub-sections: this section is disproportionately short (14 pp.) - see LCL 6:606-607

(a) 2.8-25 - Virtues required of a legislator; enduring validity and permanence of Moses's laws, which have been widely acknowledged

(b) 2.26-44 - Universal acclaim of Mosaic legislation seen in LXX translation by Ptolemy II Philadelphus;

(c) 2.45-65-Moses's legislative wisdom reflected in two-fold organizational structure of Pentateuch: The historical part reports the creation of the world and early Israelite history, while the commands and prohibitions specify which behaviors are acceptable. The internal logic: ethics grounded in cosmology. Noah an example of virtue.

$2.66-186$ - Moses as (high) priest (28 pp.)

(a) 2.66-67 - Moses's priestly qualities - piety ( $\varepsilon \dot{\sigma \varepsilon} \beta \varepsilon\llcorner\alpha)$ as the chief requirement; his reception of oracles; his moderation;

(b) 2.68-70 - Moral purity as preparation for receiving oracles, forty days on the mountain, glistening countenance (cf. Exod 24:15-18; 34:29-35);

(c) 2.71-76 - On the mount, receives instructions for building and furnishing the tabernacle, using Platonic categories;

(d) 2.77-83 - Construction of tabernacle (cf. Exod 26:15-30);

(e) 2.84-88 - Woven materials, curtains, and veil (cf. Exod 26:1-14, 31-37);

(f) 2.89-93 - Tabernacle floorplan simulates temple; dimensions explained (cf. Exod 27:9-18);

(g) 2.94-108 - Sacred vessels, furnishings, fixtures-ark, candlestick, table, altars, etc. - and their symbolic significance (cf. Exod 25:10-40; 27:1-8);

(h) 2.109-135 - High priest's vestments and their significance (cf. Exod 28);

(i) 2.136-140 - Brazen laver constructed from voluntary offerings of precious metals, and its symbolic significance (Exod 38:26-27);

(j) 2.141-145 - Selection of his brother (Aaron) as high priest, and his sons as priests (cf. Exod 29; Lev 8);

(k) 2.146-160 - Eight-day dedicatory celebration-Moses's anointing of fixtures, high priest; dedicatory offerings and sacrifices; prayers as heavenly flame (Lev 8-9);

(l) 2.161-173 - Golden calf incident (Exod 32);

(m) 2.174-179 - Priestly orders, tensions between "temple attendants" and priests, and resolution of tensions by Moses with twelve rods (Num 16:1-3; 17);

(n) 2.180-186 - Rod with Aaron's name on it becomes budding plant; fruits, nuts, their significance

2.187-291 - Moses as prophet, culminating with his prophecy of his own departure from the earth. (27 pp.)

2.187-191 - Different types of prophetic experience, two of which apply to Moses: (a) his receiving an oracle given in answer to question, and (b) his own prophetic inspiration. Four examples of each type. 
2.192-245 - Prophetic oracle answering a question, in which God and Moses cooperate

(a) 2.192-208 - Punishment for blaspheming God (cf. Lev 24:10-16);

(b) 2.209-220 - Punishment for violating the Sabbath (Exod 31:14; 35:2; Num $15: 32-36)$;

(c) 2.221-232 - Demands, e.g., mourning rites, that conflict with Passover observance (Num 9:1-14);

(d) 2.233-245 - Instructions about the laws of inheritance (Num 27:1-11)

2.246-287 - Moses's own prophetic experience

(a) 2.246-257 - Predicting the parting the Red Sea and destroying the Egyptians (Exod 14)

(b) 2.258-269 - Prayer for manna, especially on the Sabbath (Exod 16:4-30)

(c) 2.270-274 - Invoking the slaughter of golden calf idolaters (Exod 32)

(d) 2.275-287 - Destruction of priestly rebels (Korah) and his companions (Num 16)

2.288-291 - Moses's prophecy of his own mysterious departure (Deut 33-34)

2.292 - Conclusion 